\title{
VIRTUAL SCREENING CAMPAIGNS ON ISOFLAVONES TO DISCOVER POTENT CYCLOOXYGENASE-2 INHIBITORS
}

\section{PENAPISAN VIRTUAL PADA ISOFLAVON DALAM PENEMUAN INHIBITOR POTEN SIKLOOKSIGENASE-2}

\author{
Enade Perdana Istyastono*) \\ Faculty of Pharmacy, Universitas Sanata Dharma, Campus 3 Paingan, Maguwoharjo, Depok, \\ Sleman, Yogyakarta, 55282
}

Received October 10, 2017; Accepted November 5, 2017

\begin{abstract}
By employing recently published structure-based virtual screening (SBVS) to identify potent cyclooxygenase-2 (COX-2) inhibitors, all isoflavones collected by ZINC15 database were virtually screened. There were 3371 isoflavones in ZINC15 database and 1356 compounds out of them met the Lipinski's rule of 5. Notably, only three isoflavones out of those 1356 compounds were identified as potent $C O X-2$ inhibitors.
\end{abstract}

Keywords: virtual screening, isoflavone, ZINC15 database, cyclooxygenase-2

\section{ABSTRAK}

Telah dilakukan penapisan virtual berbasis struktur pada seluruh isoflavone yang dikoleksi oleh basis data ZINC15 dengan memanfaatkan protokol yang sudah divalidasi secara retrospektif. Pada basis data ZINC15 didapati ada 3371 isoflavon dengan 1356 yang memenuhi Lipinski's rule of 5. Dari 1356 isoflavon tersebut hanya 3 yang teridentifikasi sebagai inhibitor poten untuk siklooksigenase-2.

Kata kunci: penapisan virtual, isoflavon, basis data ZINC15, siklooksigenase-2

\section{INTRODUCTION}

Computational medicinal chemistry tools especially structure-based virtual screening (SBVS) campaigns have become a routine of work in drug discovery (Chen, 2015; Weiss et al., 2016). Recently, an SBVS protocol to identify potent cyclooxygenase-2 has just published (Istyastono, 2017). The protocol uses PLANT1.2 docking software (Korb et al., 2009, 2007), PyPLIF (Radifar et al., 2013a, 2013b), and the best decision tree resulted from binary quantitative structureactivity analysis of the results in retrospective validation using DUD-E (Mysinger et al., 2012). Compared to previously published SBVS protocols (Huang et al., 2006; Istyastono, 2016; Krüger and Evers, 2010; Mysinger et al., 2012; Yuniarti et al., 2011), this protocol shows better predictive ability with enrichment factor (EF) value of 273.166 (Istyastono, 2017). The SBVS protocol with substantially better predictive ability offers opportunities to efficiently discover novel inhibitors for cyclooxygenase-2 (COX-2).

Isoflavones are very well known as phytoestrogens and correlated to breast cancer

*Corresponding author: Enade Perdana Istyastono

Email:enade@usd.ac.id 
due to their estrogenic activities (Dixon, 2004; Helferich et al., 2008; Varinska et al., 2015). Nevertheless, a selective COX-2 inhibitor celecoxib was reported having estrogenic activity by binding to estrogen receptor alpha (Istyastono et al., 2015), which indicates that there are some similarities in the ligand binding to $\mathrm{COX}-2$ and to estrogen receptor alpha. Therefore, the other way around, it is of considerable interest to identify novel potent COX-2 inhibitors by screening on isoflavones.

The research presented in this article aimed to discover isoflavones as novel potent COX-2 inhibitors. The SBVS protocol constructed and retrospectively validated by Istyastono (2017) to identify potent COX-2 inhibitors were employed to virtually screen isoflavones collected in the ZINC15 database (Sterling and Irwin, 2015). Three isoflavones were identified in the research presented in this article.

\section{METHODS}

\section{Materials}

Main materials used in this research are the compounds collected in ZINC15 database, which could be accessed in http://zinc15.docking.org/ (Sterling and Irwin, 2015). Only compounds with isoflavone substructure (Figure 1) were selected. The compounds were downloaded in the SMILE formats and subsequently subjected to SBVS protocol to identify potent COX-2 inhibitors developed by Istyastono (2017).

\section{Instrumentations}

Similar to Istyastono (2017), all computation were performed on a Linux (Ubuntu 10.04 LTS Lucid Lynx) machine with Intel(R) Xeon(R) CPU E3-1220 as the processors (Quad-Core @ $3.10 \mathrm{GHz}$ ) and 8.00 GB of RAM. The applications employed in this research were SPORES (ten Brink and Exner, 2009), PLANTS1.2 (Korb et al., 2009, 2007), Open Babel 2.2.3 (O’Boyle et al., 2011), and PyPLIF 0.1.1 (Radifar et al., 2013b).

\section{Procedures}

\section{Ligand Preparation}

In the drawing module in the ZINC15 database website (http://zinc15.docking.org /substances/home), isoflavone (Figure 1) was built and subsequently the button "Substructure" was clicked. All listed compounds were then downloaded in their SMILES format. Subsequently, the downloaded compounds were filtered using -filter module in OpenBabel to select only compounds that meet the Lipinski's rule of five (Lipinski et al., 2001), for example by using the following script: "obabel -ismi splitted/isoflavone.\$i.smi -osdf -O temp.sdf -gen2d | obabel -isdf temp.sdf -osmi --filter "HBD<5 HBA1<10 MW<500 $\log \mathrm{P}<5 " \quad>$ filtered_lipinski-ro5/np.\$i.smi”. All remaining compounds were then subjected in the ligand preparation process as described in Istyastono (2017).

\section{Virtual Screening Campaign}

All prepared ligands in threedimensional form and mol 2 formats resulted in the previous section were subjected to molecular docking simulations for five times independently using PLANTS1.2 and the protein-ligand interactions of all docked poses were identified and the ensPLIF values were calculated (Istyastono, 2017). Based on the ensPLIF values resulted in this research and the decision tree presented in Figure 1 in (Istyastono, 2017), the potent COX-2 inhibitors were identified.

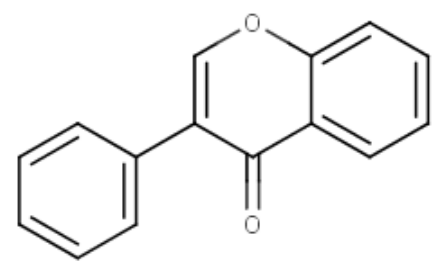

Figure 1. Isoflavone structure 


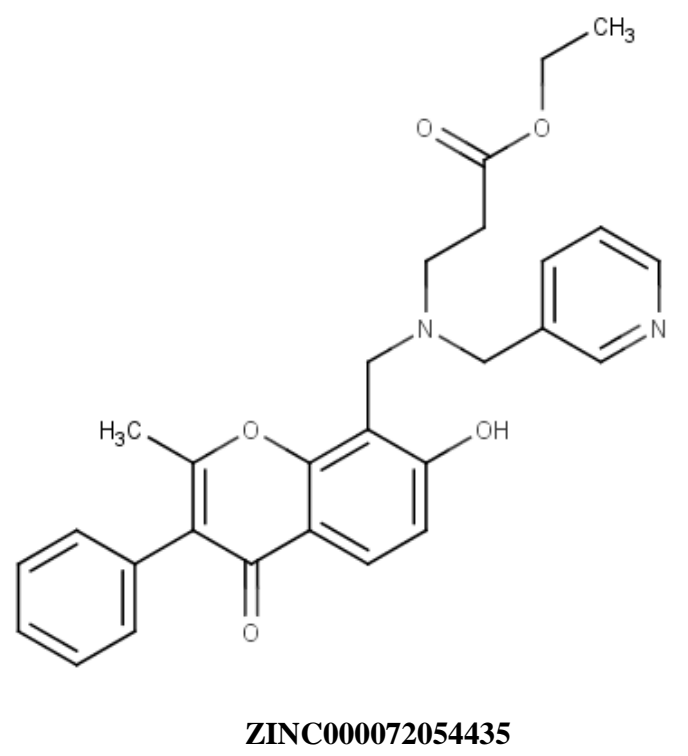<smiles>O=c1c(-c2cccc(O)c2O)coc2cc3c(c(O)c12)OCO3</smiles>

ZINC000149610875<smiles>COc1ccc(-c2coc3c(O)c(O)ccc3c2=O)cc1OC</smiles>

ZINC000034194055/CHEMBL1290567

Figure 2. Identified potent COX-2 inhibitors

\section{RESULTS AND DISCUSSION}

The ZINC15 database contains over 100 million purchasable compounds (Sterling and Irwin, 2015). Notably, there were 3371 compounds containing an isoflavone substructure (Figure 1) could be downloaded from the ZINC15 database. By employing -filter module in OpenBabel (O'Boyle et al., 2011), the isoflavones in the ZINC15 database were filtered and 1356 out of them that passed the filtering using the Lipinski's rule of 5.

By employing retrospectively validated SBVS protocol to identify potent COX-2 inhibitors (Istyastono, 2017), all remaining compounds were virtual screened. It had been expected that there would be many isoflavones identified as potent COX-2 inhibitors due to the fact that a selective COX-2 inhibitors celecoxib showed potent inhibition toward estrogen receptor alpha (Istyastono et al., 2015). However, only three isoflavones were identified as potent COX-2 inhibitors (Figure 2). Therefore, the idea about similarities between binding pocket of COX-2 and estrogen receptor alpha (Istyastono, 2017) should be revisited.

Notably, one out of three identified potent inhibitors for COX-2 (ZINC000034194055) could also be found in the ChEMBL database as CHEMBL1290567 (Bento et al., 2014). The compound was reported having activity as an antioxidant (Mitra et al., 2010). The activity of this compound as COX-2 inhibitor should be verified in vitro, which could also be used for external validation.

\section{CONCLUSION}

Three isoflavones in the ZINC15 database were identified as potent COX-2 inhibitors in SBVS campaigns using retrospectively validated protocol by Istyastono (2017). Further in vitro verification is required to establish the activity of those compounds as COX-2 inhibitors. Priority should be given to ZINC000034194055 (CHEMBL1290567) which was also reported as an antioxidant. 


\section{REFERENCES}

Bento, A.P., Gaulton, A., Hersey, A., Bellis, L.J., Chambers, J., Davies, M., Krüger, F.A., Light, Y., Mak, L., McGlinchey, S., Nowotka, M., Papadatos, G., Santos, R., Overington, J.P., 2014. The ChEMBL bioactivity database: An update. Nucl. Acids Res., 42 (D1), 10831090.

Chen, Y., 2015. Beware of docking! Trends Pharmacol. Sci., 36 (2), 78-95.

Dixon, R.A., 2004. Phytoestrogens. Апnи. Rev. Plant Biol., 55 (1), 225-261.

Helferich, W.G., Andrade, J.E., Hoagland, M.S., 2008. Phytoestrogens and breast cancer: a complex story. Inflammopharmacology, 16 (5), 219 226.

Huang, N., Shoichet, B.K., Irwin, J.J., 2006. Benchmarking sets for molecular docking. J. Med. Chem., 49 (23), 67896801.

Istyastono, E.P., 2016. Optimizing structurebased virtual screening protocol to identify phytochemicals as cyclooxygenase-2 inhibitors. Indones. J. Pharm., 27 (3), 163-173.

Istyastono, E.P., 2017. Binary quantitative structure-activity relationship analysis to increase the predictive ability of structure-based virtual screening campaigns targeting cyclooxygenase- 2 . Indones. J. Chem., 17 (2), 322-329.

Istyastono, E.P., Riswanto, F.D.O., Yuliani, S.H., 2015. Computer-aided drug repurposing: a cyclooxygenase-2 inhibitor celecoxib as a ligand for estrogen receptor alpha. Indones. $J$. Chem., 15 (3), 274-280.

Korb, O., Stützle, T., Exner, T.E., 2007. An ant colony optimization approach to flexible protein-ligand docking. Proc. IEEE Swarm Intell. Symp., 1 (2), 115 134.

Korb, O., Stützle, T., Exner, T.E., 2009. Empirical scoring functions for advanced protein-ligand docking with PLANTS. J. Chem. Inf. Model., 49 (1), 84-96.

Krüger, D.M., Evers, A., 2010. Comparison of structure- and ligand-based virtual screening protocols considering hit list complementarity and enrichment factors. ChemMedChem, 5 (1), 148-158.

Lipinski, C.A., Lombardo, F., Dominy, B.W., Feeney, P.J., 2001. Experimental and computational approaches to estimate solubility and permeability in drug discovery and development settings. Adv. Drug Deliv. Rev. 46 (1-3), 3-26.

Mitra, I., Saha, A., Roy, K., 2010. Chemometric modeling of free radical scavenging activity of flavone derivatives. Eur. J. Med. Chem., 45 (11), 5071-5079.

Mysinger, M.M., Carchia, M., Irwin, J.J., Shoichet, B.K., 2012. Directory of Useful Decoys, Enhanced (DUD-E): Better ligands and decoys for better benchmarking. J. Med. Chem., 55 (14), 6582-6594.

O’Boyle, N.M., Banck, M., James, C.A., Morley, C., Vandermeersch, T., Hutchison, G.R., 2011. Open Babel: An open chemical toolbox. J. Cheminform. 3 (1), 33-47.

Radifar, M., Yuniarti, N., Istyastono, E.P., $2013^{\mathrm{a}}$. PyPLIF-assisted redocking indomethacin-(R)-alpha-ethylethanolamide into cyclooxygenase-1. Indones. J. Chem., 13 (3), 283-286.

Radifar, M., Yuniarti, N., Istyastono, E.P., 2013 ${ }^{\text {b }}$. PyPLIF: Python-based ProteinLigand Interaction Fingerprinting. Bioinformation, 9 (6), 325-328.

Sterling, T., Irwin, J.J., 2015. ZINC 15 Ligand discovery for everyone. J. Chem. Inf. Model. 55 (11), 2324-2337.

ten Brink, T., Exner, T.E., 2009. Influence of protonation, tautomeric, and stereoisomeric states on protein-ligand docking results. J. Chem. Inf. Model., 49 (6), 1535-1546.

Varinska, L., Gal, P., Mojzisova, G., Mirossay, L., Mojzis, J., 2015. Soy and breast cancer: Focus on angiogenesis. Int. J. Mol. Sci., 16 (5), 11728-11749.

Weiss, D.R., Bortolato, A., Tehan, B., Mason, J.S., 2016. GPCR-Bench: A benchmarking set and practitioners' 
guide for $\mathrm{G}$ protein-coupled receptor docking. J. Chem. Inf. Model., 56 (4), 642-651.

Yuniarti, N., Ikawati, Z., Istyastono, E.P., 2011. The importance of ARG513 as a hydrogen bond anchor to discover COX2 inhibitors in a virtual screening campaign. Bioinformation, 6 (4), 164166. 